\section{AB0139 IMPACT OF OBESITY ON DEGENERATIVE RADIOGRAPHIC FINDINGS}

A Atalay, S Arslan, R Çeliker. Physical Medicine and Rehabilitation, Hacettepe University, School of Medicine, Ankara, Turkey

10.1136/annrheumdis-2001.401

Background Obesity is a growing problem in all countries which is considered to be one of the most important concerns for public health. For clarification of the topic, further research about morbidity of the problem should be considered.

Objectives The purpose of this study was to assess degenerative radiographic findings of the spine, pelvis and knees related with obesity.

Methods 71 female patients from our outpatient clinics were enrolled in the study. Cut-off points for obesity were determined according to guidelines of World Health Organisation (WHO). Cut-off values are as follows: 18.5-24.99: normal, 25.0-29.99 grade1 overweight, 30.0-39.99 grade 2 overweight, $>=40.0$ grade 3 overweight. Beside demographic data, radiologic assessment by plain radiographs of the spine, pelvis and knees were obtained. Antropometric measurements including height, body weight, abdominal circumference, waist circumference, triceps skinfold thickness were performed by the same physician. Body mass index (BMI) was calculated as $\mathrm{kg} / \mathrm{m}^{2}$. Radiographs were evaluated by a physician blind to the clinical status of that particular patient. For radiologic evaluations Kellgren-Lawrence score was utilised. $\mathrm{p}<0.05$ was considered to be statistically significant.

Results The mean age of the subjects was $52.70 \pm 11.25$ years (range: $25-78$ years) and mean BMI was $31.17 \pm 5.70$ (range: 21.91-47.27). Degenerative changes in lumbar spine and knees are shown in Table 1.

BMI was positively correlated with degenerative changes in the knee even when controlled for age $(p=0.000)$. Radiographs of the knee was also found to be correlated with body weight abdominal circumference, waist circumference, triceps skinfold thickness. Radiologic score of the knees were found to be correlated with scores of the pelvis and lumbar spine. But radiologic scores of pelvis and lumbar spine were not correlated with antropometric measures.

\begin{tabular}{llllll}
\multicolumn{7}{l}{ Abstract AB0139 Table 1 } \\
\hline $\begin{array}{l}\text { Grade } 0 \\
(\%)\end{array}$ & $\begin{array}{l}\text { Grade I } \\
(\%)\end{array}$ & $\begin{array}{l}\text { Grade II } \\
(\%)\end{array}$ & $\begin{array}{l}\text { Grade III } \\
(\%)\end{array}$ & $\begin{array}{l}\text { Grade IV } \\
(\%)\end{array}$ \\
\hline Lumbar & 21.4 & 32.9 & 20.0 & 24.3 & 1.4 \\
Knee & 32.4 & 40.0 & 8.5 & 14.1 & 4.2 \\
\hline
\end{tabular}

Conclusion Radiographic findings in the knee was found to be correlated with BMI and other anthropometric measures when controlled for age but there was no correlation between obesity and radiographs of the pelvis and lumbar spine.

\section{REFERENCES}

1 Felson DT, Zhang Y, Anthony JM, et al. Weight loss reduces the risk for symptomatic knee osteoarthritis in women. Ann Intern Med. 1992:116:535-9

2 Sharma L, Lou C, Cahue S, et al. The mechanism of the effect of obesity in knee osteoarthritis. Arthritis Rheum. 2000;43:568-75

3 Stürmer T, Günther KP, Brenner H. Obesity, overweight and patterns of osteoarthritis: The Ulm Osteoarthritis Study. J Clin Epidemiol. 2000;53:307-13

\section{AB0140 THE EVALUATION THE FACTORS THAT EFFECT THE CLINICAL STATUS OF PATIENTS WITH PRIMARY KNEE OSTEOARTHRITIS}

H Tuna, A Hakgüder, G Ekuklu, S Kokino. Physical Medicine and Rehabilitation, Medical Faculty of Trakya University, Edirne, Turkey

\subsection{6/annrheumdis-2001.402}

Background Primary knee osteoarthritis (PKO) leads functional degenaration of knee joints and cause disability in general population. There are a lot of faýctors that effect on the intensity and functional status of PKO in various degrees.

Objectives To investigate the efficacies of age, body mass index (BMI), the Kellgren Lawrence Radiological Osteoarthiritis Index (KLOAI), medial tibiofemoral joint space (MTFJS) on the intensity and functional status of PKO.

Methods Fifty subjects (ages 56 to 69), 40 female (\%80) and 10 male (\%20), diagnosed as PKO according to American College of Rheumotology were admitted to the study. AP knee radiography of the patients were taken while standing up and MTFJS were measured. Those films were evaluated according to the KLOAI. Lequesne index (LI), Sickness Impact Profile (SIP), painless walking duration (PWD1) and painless walking distance (PWD2) were used with purpose to determine the clinical status and intensity of the PKO.

Results We found these formulas according to Backward Lineer Regression Model.

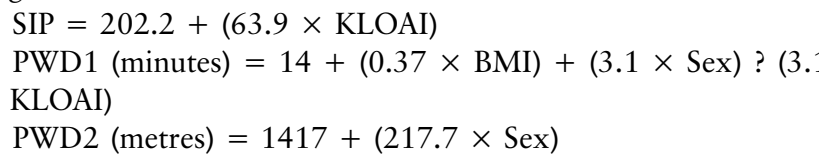

Conclusion KLOAI correlated with SIP and PWD1 moderately. However, we think that all of these factors should be evaluated in clinical status of PKO.

\section{REFERENCES}

1 Mc Alindon TE, Cooper C, Kýrwan JR. Determinants of disability in osteoarthritis of the knee. Ann Rheum Dis. 1993:52:258-62

2 Hochberg MC, Cejku ML, Scott WW. The association of body weight, body fatness and body fat distribution with osteoarthritis of the knee: data from the Baltýmore longitudinal study of aging. J Rheumatol. 1995;22(3):488-93

3 Mankin HJ. Clinical features of osteoarthritis. In: Kelly, Harris, Rudd, Sledge, eds. Textbook of rheumatology. Vol. 4. Philadelphia: WB Saunders Company, 1993: 1374-84

4 Lequesne MG, Samson M. Indicis of severity for OA. Eular Balot No:3, 85, 1992

5 Wade DT. Measurement in neurological rehabilitation. Oxford University Press, 1992: 208

6 Sowers M, Zobel D, Weis FF. Progression of osteoarthritis of the hand and metacarpal bone loss. Arthritis Rheum. 1991;34(1):36-42

7 Dequeker J, Dieppe P. Disorders of bone, cartilage and connective tissue. In: Klippel JH, Dieppe PA, eds. Rheumatology. Philadelphia: The Mosby Company, 1998: 8.1.1-8.12.16

\section{AB0141 THE FIRST EXPERIENCE OF THE EFFICACY AND SAFETY OF COXIBS IN TURKISH NATION}

N Eskiyurt. Physical Therapy and Rehabilitation, Istanbul School of Medicine, Istanbul, Turkey

10.1136/annrheumdis-2001.403

\section{Background}

Objectives To evaluate the efficacy and safety of the first COXIB, namely Rofecoxib in the Turkish osteoarthritis (OA) patients.

Methods The study included a total number of 138 patients with hip or knee osteoarthritis diagnosed according to the ACR 